\title{
Multimedia Sanako study 1200 for TEFL in institution of higher education
}

\author{
Oksana Y. Amurskaya - Gulnara K. Gimaletdinova - Liliia K. Khalitova
}

\section{DOI: 10.18355/XL.2017.10.03.18}

\begin{abstract}
This paper presents a case study of using multimedia laboratory Sanako 1200 for teaching English as a foreign language (TEFL) at Kazan Federal University. The research outlines the basic functions and features of the software Sanako 1200, determining the benefits and drawbacks of this multimedia study in TEFL, and provides practical examples of its usage. The current interest in the problem lies in the growing popularity of the computer-assisted language learning (CALL) in higher education. On the one hand, with CALL technologies, instructors diversify TEFL methods and means, but on the other, introducing computer technologies can be challenging for teachers and learners. The purpose of the study was to reveal whether university students and teachers consider Sanako beneficial for their English language learning/teaching. The data used in this study come from quantitative (closed-and open-ended response questionnaire) and qualitative (face-to-face interview) methodology. To collect the data, second-, third- and fourth-year students $(\mathrm{N}=135)$ were asked to complete a questionnaire and teachers $(\mathrm{N}=10)$ were interviewed. The findings indicate to high motivation of university students to apply multimedia training tool Sanako in EFL learning. However, a number of technical hurdles revealed require special consideration of the problem. The findings have important implications for further use of Sanako labs at university.
\end{abstract}

Key words: Sanako study 1200, multimedia, TEFL, CALL

\section{Introduction}

With the development of computer technologies in the system of higher education the computer-assisted language learning (CALL) has occupied a firm place in teaching English as a foreign language (EFL) research and practice. Latest CALL literature indicate a special interest in integrating computer technologies into the EFL classes, e.g. Lim \& Shen, 2006, Chapelle, 2010, Sadykova, 2014, Wrobel, 2015. However, little do we have research in which Sanako software is evaluated by both university students and teachers in the terms of their issues and concerns (see, e.g. Idri, 2015, Panasyuk, 2013, Filatova \& Shiryaeva, 2008). Sanako Study 1200 (Finland) is a software developed to assist in learning by means of the multimedia connection LAN. Sanako Study 1200 "has allowed modern language teachers to customize their language classes and make more efficient use of lab time in conducting exams" (Wrobel, 2015). The modern language program, which provides 13 languages to study, enabled to replace the tape laboratory by the one equipped with Sanako software.

Sanako labs are used in over 100 countries in universities, colleges, and schools worldwide including, Oakton Community College (Illinois, USA), Bristol University (UK), Blessed Thomas Holford Catholic College (UK), Bootham School (UK), Saint-Petersburg State University and Moscow State University (Russia). Sanako provides modern facilities for reading, listening and speaking activities and teachers benefit from it at translation classes, phonetic courses and EFL classes. The following methodological principles are considered: 1) correlation with speech practice, reading and writing as the basic aspects of EFL; 2) high informative value, 
motivation and appeal; 3) comprehension availability. Sanako laboratory develops students' listening skills in various modes (Panasyuk, 2013).

To point out these principles, it is necessary at this point to describe the main characteristics of Sanako Study 1200, the interface of which on the head computer is presented in Figure 1.

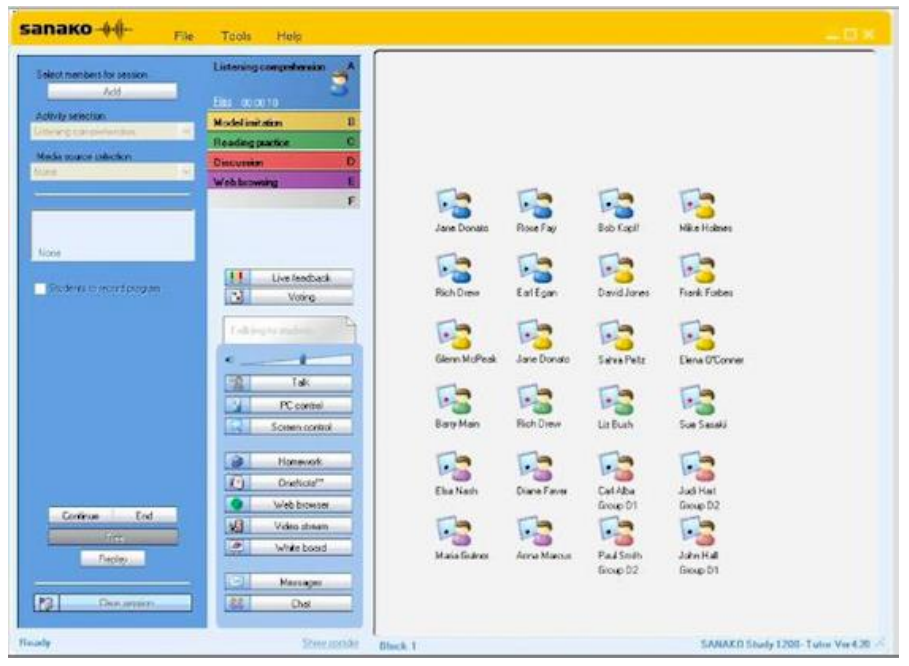

Fig. 1. The interface of Sanako Study 1200 (the head computer)

As shown in Figure 1, students' icons occupy the right part of Sanako interface. Students use their logins and passwords to sign in. Once they sign in, their icons are activated on the teacher's computer, what enables him to create "a virtual classroom". The basic educational instruments of Sanako operation, presented on the left in the menu (Fig.1), are the following: Activity selection, Media source selection, Web policy selection, Talk, PC control, Screen control, Student application, Messages and Chat aimed to engage students into learning a language.

Sanako Study 1200 software is applicable to both young and school learners aged 7-17 providing opportunities for creativity (e.g. text synchronization and subtitling). The function of Sanako that enables to transfer the image from a teacher's screen on the students' monitors provides the possibility to use the educational CDs in their classes. Sanako suggests audiovisual facilities such as broadcasting the video from the head computer to the students' computers. Internet access provided, learners may apply various Internet resources in their EFL learning. The white board function is used to transfer images to the learners' screens. Sanako is aimed at reaching modern goals in education, increasing learners' motivation. The multimedia facilities develop student-centered approach and stimulate independent learning (Filatova \& Shiryaeva, 2008).

The focus on the approach and methodology correlates with the key methodological principles Sanako is based on. A virtual classroom is activated on the teacher's computer, and the basic educational instruments of Sanako operation include Activity selection, Media source selection, Web policy selection, Talk, PC control, Screen control, Student application, Messages and Chat. Sanako Study 1200 supports two modes of education: the mode of study and the mode of self-study. 
Discussion mode improves speaking skills since Sanako software enables students to work in paired activities or with randomly selected partners during seminars without the distractions of background noise. Round table group discussions with the appointed moderators for each group support group work engaging each member and provide a teacher with the opportunity of monitoring and recording discussions and observing the results achieved.

The self-study mode in Sanako laboratory enables a teacher to send a file with assignments, record students' speech and distribute the recording to other students for self-correction, self-evaluation, encouraging independent learning. Students' writing (spelling) skills are practiced in common chat controlled by a teacher where they can ask questions or add comments. Thus students can gradually develop the skills of independent learning by analysing their strengths, weaknesses, outlining areas for improvement and determining special interests related to the subject. Figure 2 demonstrates one of aspects of students' independent learning: listening comprehension.

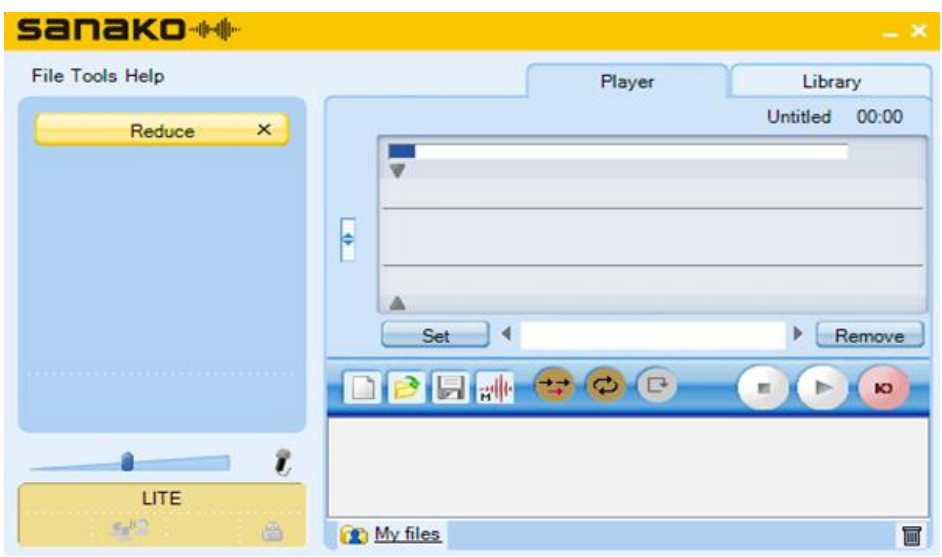

Fig. 2. An audio player on students' screens

Another module of Sanako study 1200 is the Examination module, in which EFL teachers apply tests to monitor students' achievements. The flexible structure of the module allows a teacher to create a tests bank, which can be improved further.

Therefore, multimedia Sanako Study 1200 corresponds to the basic principles of TEFL at university level:

1. A teacher is not a central figure of the learning process, but a facilitator, controlling, monitoring and encouraging the adult learners.

2. Self-study facilities gradually make university students more responsible, independent and self-confident (Abdrafikova \& Konopatskaya, 2014). Sanako options of self-correction and self-evaluation stimulate students' self-improvement.

3. Collaborative activities promote live communication (Sadykova, 2014).

4. Audiovisual facilities enlarge authentic vocabulary and improve communicative skills (Sherman, 2003).

In 2012 Kazan Federal University was equipped with Sanako laboratories (Linguaphone, 2012) including hardware, headphones, projector and the software Sanako Study 1200. Thirty-five classrooms were transformed into computer language laboratories. Teachers were provided with multiple instruments to manage classwork in a motivating and effective way. Priority was given to EFL classes and over 100 teachers were trained to work in that system. 
Thus, Sanako Study 1200 was introduced in the course of ESL speech practice and enabled the Kazan University teachers to implement some Internet activities suggested by British council on its website where "students can watch the videos individually on computers (with headphones)" (Megabridges, 2012). This was successfully implemented with the fourth-year students of Kazan Federal University. As a result, students enjoyed working individually on their own pace, listening to native speakers, discovering new information and collaborating with groupmates.

Sanako Study 1200 has recently been applied in the course of synchronous translation. The equipment of a language laboratory is approximated to the environment of an interpreter (a cabin, headset and incoming voice sound). Interpretation classes in a Sanako Laboratory involve such activities as: 1) watching a video on Youtube and interpreting the speaker simultaneously and consecutively; 2) listening to an interview with a celebrity and interpreting it partly or completely; 3) interpreting a weather forecast, a news report or a talk-show on Youtube. Internet access allows the teachers to choose different types of texts and speakers for interpretation, which models real-life situations. Due to Sanako Lab environment, every student is engaged in the process of interpretation and does it in his/her own pace, and the teacher can monitor the progress and assist.

The paper emphasizes the importance of integrating Sanako Study 1200 software in academic courses for TEFL in institution of Higher Education and presents Kazan Federal University students' and teachers' impressions from the application. The research questions for this study are:

1. Do the students consider lessons with Sanako 1200 beneficial for their English language learning? If yes, in what aspects?

2. What are the teachers' issues and concerns about classes with multimedia lab Sanako 1200 at Kazan Federal University?

\section{Methodological framework}

The study investigates both student and teacher perceptions of useful and challenging components of learning / teaching experiences about integrating Sanako 1200 software at Kazan Federal University. The study examines if students consider Sanako 1200 as a useful and beneficial learning software that could strengthen and improve learning EFL and enhance particular learning skills (writing, reading, listening or speaking). With such knowledge, researchers and educators will develop appropriate recommendations for further integration of the multimedia lab.

The research is a two-stage, mixed method study (see Table 1). In the first stage one hundred and thirty five ( $\mathrm{N}=135,23$ males and 112 females) second-, thirdand fourth-year students learning EFL were randomly chosen to participate in the survey. Paper-based questionnaires were used for data collection. The researchers contacted the participants in person and asked to fill a five-question form (see Appendix 1) on a voluntary basis, which was returned upon completion. The survey included closed-ended questions related to participants' language-learning activities and reflective assessment of the course and open-ended questions concerning the courses the students had and benefits and drawbacks of the Sanako Study 1200.

The second stage included face-to-face interviews with ten $(\mathrm{N}=10)$ teachers who were asked four open-ended questions concerning the experience (both positive and negative) and to what extent the possibilities of Sanako 1200 correspond their academic courses. Table 1 shows data source, number of participants and a method of data analysis for both research stages.

Table 1. Data Sources, Participants and Methods of Data Analysis 


\begin{tabular}{|c|c|c|c|}
\hline Stages & $\begin{array}{l}\text { Data } \\
\text { source } \\
\end{array}$ & Participants & Method of data analysis \\
\hline Stage 1 & Survey & $\begin{array}{l}135 \text { students who } \\
\text { learned EFL in a } \\
\text { multimedia classroom } \\
\text { Sanako } 1200 \text { as part of } \\
\text { their academic course(s) }\end{array}$ & $\begin{array}{l}\text { Quantitative } \\
\text { questions No 2, } 3 \text { and open- } \\
\text { ended questions No } 1,4,5 \text { ) }\end{array}$ \\
\hline Stage 2 & $\begin{array}{l}\text { Face-to- } \\
\text { face } \\
\text { interview }\end{array}$ & 10 teachers & Qualitative (coding for themes) \\
\hline
\end{tabular}

In this study we used both quantitative (closed response question questionnaire) and qualitative (interview) research methodology (see Appendix 1 and Appendix 2).

\section{Results and discussion \\ Sanako study 1200 in an EFL classroom at Kazan Federal University}

The study revealed that the following academic courses involved Sanako Study 1200 at Kazan Federal University: Phonetics, EFL (practical course), Linguistic and Cultural Studies, Interpretation and Translation Studies and the course of Old Germanic languages. Listening activities are the most commonly used by various teachers who work at Sanako Study labs. Listening activities are regarded as the most appealing to students. The results of the survey also show that developing writing skills at a Sanako Study lab is relatively unclaimed by teachers, therefore, students having little practice with it, do not appreciate the activity either (see Table 2).

Table 2. Activities with Sanako study 1200: students' preferences

\begin{tabular}{|l|l|l|}
\hline Activities & $\begin{array}{l}\text { Total } \\
(\text { raw N=135) }\end{array}$ & $\begin{array}{l}\text { Most liked } \\
(\text { raw N=135) }\end{array}$ \\
\hline Listening & 132 & 120 \\
\hline Speaking & 45 & 27 \\
\hline Writing & 9 & 0 \\
\hline Reading & 57 & 23 \\
\hline Other & 27 & 15 \\
\hline
\end{tabular}

Two open-ended questions asked to the students comprised the issues of challenges they faced applying Sanako and the efficiency of using the multimedia while learning EFL. As the results indicate, $98 \%$ of students $(\mathrm{N}=132)$ involved in the survey do not consider working at Sanako Study lab challenging, though they mentioned the following drawbacks: problems with logging in, poor Internet connectivity and Internet disconnection and slow downloading. 99\% of Kazan University students (N=133) admitted that using Sanako Study 1200 was beneficial to learning EFL, improved learning English in general and their speaking and listening skills in particular. Occasionally two students claimed that because of technical problems (Internet disconnection and slow information downloading) the work at the Sanako lab was non-productive and time consuming, which made it less efficient compared with a traditional academic class.

In Stage Two of the research ten teachers having at least ten years of teaching experience in Kazan Federal University $(\mathrm{N}=10)$ were asked four questions concerning the frequency of using Sanako at their lessons, to what extend the software fits their academic courses and their issues and concerns (see Appendix 2). The 
questionnaire was followed by an interview consisting of some additional specifying questions (follow-up interview).

Each interview session was conducted face-to-face, individually and took approximately 20 minutes. The interviews were recorded with the permission of the participants. The results of this interview reveal that six teachers $(\mathrm{N}=6)$ use Sanako 1200 each time they have classes in the laboratories, the other four teachers $(\mathrm{N}=4)$ responded that they use it "not always, from time to time" due to 1) the software that does not perfectly fit all their academic courses and 2) technical problems. All teachers $(\mathrm{N}=10)$ emphasized that the software gives an opportunity to control and monitor the students' achievements as well as to encourage students of lower levels and shy learners which corresponds to a student-centered approach in TEFL.

"Conducting lessons with Sanako 1200 is beneficial because it allows me to teach creatively and students enjoy the classes. When some technical problems occur, like, a long log in time or poor Internet connection, I prefer not to waste time and do without Sanako." (EFL teacher, follow-up interview)

"Classes with Sanako 1200 fit perfectly my EFL classes, as there is an option for individual listening. I have a class with different comprehension ability students, so listening at their own pace is an excellent solution to the problem!" (Teacher of Phonetics, followup interview)

The quotes illustrate overall positive impression of the course, however show that technical problems might be distractive and time consuming.

The interview with teachers revealed drawbacks concerning online work. Five teachers $(\mathrm{N}=5)$ indicated that students often get distracted from the classwork by the Internet-sites unrelated to their studies. Another challenge with chat-sessions was discussed by two teachers $(\mathrm{N}=2)$ who admitted that chat-activities proved to be useful in receiving feedback and training English spelling, but students need to be supervised. They pointed that it is highly recommended to terminate chat-sessions as soon as students switch to their mother tongue.

\section{Conclusion}

The research analyses the application of multimedia Sanako study 1200 as a supplementary and supporting CALL technology used in learning EFL at Kazan Federal University. The interest of the study lies on students' and teachers' perceptions of Sanako 1200. The data revealed that Sanako meets the demands of the university students since they are highly motivated to apply complementary multimedia training tools in foreign language learning. The results indicate that the equipment of a language classroom is one of key factors that stimulate and improve learning EFL at a modern institution of higher education. Due to wide range possibilities, e.g. video and listening activities and chat-rooms students and teachers believe Sanako multimedia lab contributes to the improvement of higher education.

The findings have significant implications for further use of Sanako labs at Kazan Federal University. The results indicate that more academic courses might benefit from using multimedia alongside with traditional learning tools and resources.

A number of technical drawbacks revealed by the study (poor Internet connection and a long log in time) show that the technical side of the problem requires special consideration.

Given freedom in Internet usage, students in some cases get easily distracted from the task provided by the teacher to other Internet-sites, which are not related to

${ }^{1}$ All participants' quotes have not been corrected for language accuracy. 
their studies. Thus, it is highly recommended for teachers to control students' activities in the Internet using the monitor function in their head computers and set reasonable time-limit to fulfill the task. The same can be referred to the chat-function, which is generally associated by students with the free talk.

Research data and theoretical considerations of the problem discussed in this study can be applied by EFL teachers to motivate their students and stimulate the learning process. Teachers who have just started introducing Sanako Study 1200 in their classroom might also find the range of activities suggested in the paper beneficial.

\section{Appendix 1.}

\section{Questionnaire for students of Kazan Federal University}

1. Which course(s) you took involved Sanako Study 1200?

2. What activities with Sanako Study 1200 did you have? (If necessary, choose more than one).

$\square$ Listening
$\square$ Speaking
$\square$ Writing
$\square$ Reading
$\square$ Other

3. What activities did you like most? (If necessary, choose more than one).

$\square$ Listening

Speaking

Writing

Reading

Other

4. Did you find anything challenging? If yes, what?

5. Did Sanako Study 1200 improve learning English?

\section{Appendix 2.}

Questions of the interview for teachers of Kazan Federal University

1. Do you always use Sanako 1200 when you have classes in the laboratory?

2. Do you find using Sanako 1200 beneficial? Why?

3. Do you find using Sanako 1200 challenging? Why?

4. Does the software Sanako 1200 fit your course?

\section{Bibliographic references}

LIM, K. - SHEN, H. 2006. Integration of computers into an EFL reading classroom.

ReCALL, 18(2), pp. 212-229. ISSN 0958-3440.

DOI: https://doi.org/10.1017/S0958344006000528.

CHAPELLE, C. 2010. The spread of computer-assisted learning. Language teaching,

43 (1), pp. 64-74. ISSN 0261-4448.

DOI: https://doi.org/10.1017/S0261444809005850.

SADYKOVA, G. 2014. Mediating Knowledge through Peer-to-peer Interaction in a Multicultural Online Learning Environment: A Case Study of International Students in the US. International Review of Research in Open and Distance Learning, 15 (3), pp. 24-49. ISSN 1492-3831. DOI: http://dx.doi.org/10.19173/irrodl.v15i3.1629.

WROBEL, B. 2015. Oakton introduces students to the world through programs in 13 modern languages and the Sanako Study 1200 multimedia language lab. Sanako

Newsletter. Retrieved March 6, 2017, from http://www.teseducatief.nl/uploads/pdf/Sanako/2015-Nieuwsbrief-Voorjaar.pdf. 
IDRI, N. A. 2015. Using multimedia labs in enhancing EFL students' research methods. University of Bejaia, 28-Sep-2015. Retrieved March 6, 2017, from http://www.univ-bejaia.dz/documents/multilinguales/7\%20IDRI\%20Nadia. PDF.

PANASYUK, I. V. 2013. Teaching of listening comprehension in multimedia language laboratory Sanako: Materialy XLII Mezhdunarodnoy filologicheskoi konferentsii 11-16 March 2013, Sankt-Peterburg. Retrieved March 6, 2017, from http://phil.spbu.ru/nauka/konferencii/arhiv/konferencii-2012-2013-gg/tezisy-tezisydokladov-xli-mezhdunarodnoi-filologicheskoi-konferencii.

FILATOVA, O. - SHIRYAEVA, O. 2008. Iz opyta ispolzovaniya multimediynoy uchebnoy sredy Sanako study $1200 \mathrm{v}$ prepodavanii inostrannogo yazyka // Primeneniye novykh tekhnologiy v obrazovanii: Materialy XIV Mezhdunarodnoy konferentsii, 26-27 June 2008, Troitsk, 2008. Retrieved March 6, 2017, from http://window.edu.ru/catalog/pdf2txt/933/55933/26988?p_page=26.

ABDRAFIKOVA, A. - KONOPATSKAYA, E. 2014. The case study technologies as the means of competency building approach realization in higher education of Russia.

English Language Teaching, 7(12), pp. 94-99. ISSN 1916-4742. DOI: http://dx.doi.org/10.5539/elt.v7n12p94.

SHERMAN, J. 2003. Using authentic video in the language classroom. Cambridge: Cambridge University Press 275 p. ISBN 0521799619.

Linguaphone software system Sanako Study 1200 (07-Sep-2012). Retrieved March 6, 2017, from http://kpfu.ru/dis/lingafonnyj-programmnyj-kompleks-sanako-study-120012640.html

Megabridges. British Council, BBC, 2012. Retrieved March 6, 2017, from http://www.teachingenglish.org.uk/article/megabridges

Words: 3142

Characters: 21902 (12,16 standard pages)

Assoc. Prof. Oksana Y. Amurskaya, PhD. (Philology)

Department of German Philology

Kazan Federal University

18, Kremlyovskaya St., 420008 Kazan

Republic of Tatarstan, Russia

oksana2181@mail.ru

Assoc. Prof. Gulnara K. Gimaletdinova, PhD. (Philology)

Department of German Philology

Kazan Federal University

18, Kremlyovskaya St., 420008 Kazan

Republic of Tatarstan, Russia

gim-nar@yandex.ru

Assoc. Prof. Liliia K. Khalitova, PhD. (Philology)

Department of German Philology

Kazan Federal University

18, Kremlyovskaya St., 420008 Kazan

Republic of Tatarstan, Russia

lilia_khalitova@mail.ru 